\title{
ANALISIS YURIDIS TERHADAP YAYASAN YANG TIDAK MENYESUAIKAN ANGGARAN DASARNYA
}

\author{
Nury Anisa, Tunggul Anshari, Nurdin \\ Program Magister KenotariatanFakultas Hukum Universitas Brawijaya \\ JI. MT. Haryono No 169; Malang; 65145; Indonesia; (0341) 553898 \\ nuryannisa93@gmail.com
}

\begin{abstract}
Foundation is a legal entity consisting of weal th that is separated and destined to achieve certain goals in the field of social, religious, and humanity that has no members. Foundation is a legal institution that has binding legal force. The existence of foundations is recognized in Indonesia both before the introduction of the Foundation Law and after the Foundation Act. The Foundation in its Articles of Association in Article 71 Paragraph 4 of the Law of the Republic of Indonesia Number 28 Year 2004 regarding Amendment of Law of the Republic of Indonesia Number 16 Year 2001 regarding the Foundation argues that a foundation that has not adapted cannot carry out its activities on behalf of the foundation but becomes a associations based on the Civil Code. The foundation which does not adjust the articles of association according to the given time period is null and void and must be liquidated. With respect to null and void, the foundation is not allowed to use the word "foundation" in front of the foundation's name which resulted in the foundation not obtaining the legal entity status and the existence degradation of the foundation's status.
\end{abstract}

Keywords: Budget, Foundation Foundation, Juridical Analysis.

\begin{abstract}
Abstrak
Yayasan merupakan badan hukum yang terdiri atas kekayaan yang dipisahkan dan diperuntukkan untuk mencapai tujuan tertentu dibidang sosial, keagamaan, dan kemanusiaan yang tidak memiliki anggota. Yayasan merupakan lembaga hukum yang memiliki kekuatan hukum mengikat. Eksistensi yayasan diakui di Indonesia baik sebelum diberlakukakannya Undang- undang Yayasan maupun setelah adanya Undang- undang Yayasan. Yayasan dalam hal anggaran dasarnya pada Pasal 71 Ayat 4 Undang-Undang Republik Indonesia Nomor 28 Tahun 2004 tentang Perubahan Undang-Undang Republik Indonesia Nomor 16 Tahun 2001 tentang Yayasan mengemukakan bahwa yayasan yang belum menyesuaikan tidak dapat melaksanakan kegiatannya atas nama yayasan, namun menjadi sebagai suatu perkumpulan berdasarkan Kitab UndangUndang Hukum Perdata.Yayasan yang tidak menyesuaikan anggaran dasar sesuai dengan jangka waktu yang diberikan maka batal demi hukum dan harus dilikuidasi. Berkaitan dengan batal demi hukum mengakibatkan yayasan tidak diperbolehkan menggunakan kata "yayasan" didepan nama yayasan yang berakibat yayasan tersebut tidak memperoleh status badan hukum dan terdegradasinya eksistensi dari status yayasan tersebut.
\end{abstract}

Kata kunci: Analisis Yuridis, Anggaran, Dasar Yayasan. 
Yayasan pertama kali berdiri di Indonesia dimulai dengan adanya kepentingan masyarakat untuk memenuhi kebutuhan-kebutuhan yang memiliki tujuan sosial, keagamaan,dan kemanusiaan dalam wujud wadah atau lembaga. Munculnya lembaga yayasan maka segala keinginan sosial, keagamaan, dan kemanusiaan itu dapat diperoleh dalam suatu lembaga dan diakui serta diterima keberadaannya. Bahkan yayasan merupakan nirlaba, artinya tujuannnya bukan mencari keuntungan, melainkan melaksanakan sesuaatu yang bersifat amal. Hadirnya yayasan di Indonesia diatur selama ini berdasarkan kebiasaan yang didukung oleh yurisprudensi memberikan pemahaman bahwa yayasan sebagai lembaga hukum tidak serta merta mencari keuntungan akan tetapi lebih memilih untuk memberikan kesejahteraan sosial.

Kegiatan beberapa yayasan yang dilakukan di Negara Indonesia khususnya antara lain memberikan kesejahteraan kepada penderita cacat fisik, memberikan santuan kepada yatim piatu, memberikan bantuan dana pendidikan kepada anak yang kurang mampu/ tidak mampu, memberikan bantuan kepada keluarga yang telah berduka serta memberikan pelayanan kesehatan kepada penderita suatu penyakit (Septiari, Firdaus, Hasanah, 2016). Namun tidak semua yayasan yang ada muncul ditengah-tengah masyarakat itu didaftarkan untuk menjadikannya suatu badan hukum berdasarkan peraturan perundang- undangan yang berlaku. Hal tersebut dikarenakan dengan berbagai persyaratan serta tujuan didirikannya lembaga tersebut menimbulkan berbagai macam jenis yayasan yang pada akhirnya kedudukan yayasan dimata hukum tidak jelas(Adjie,2013).

Undang-Undang Yayasan telah disahkan pada tahun 2001 sebelum diberlakukannya Undang-Undang Republik Indonesia Nomor 16 Tahun 2001 tentang Yayasan yang kemudian di amandemen menjadi Undang-Undang Republik Indonesia Nomor 28 Tahun 2004 tentang Perubahan Undang-Undang Republik Indonesia
Nomor 16 Tahun 2001 tentang Yayasan dapat dikatakan bahwa dasar hukum yang berlaku untuk yayasan adalah hukum kebiasaan yang timbul dengan sendirinya dalam masyarakat yang terjadi karena kebutuhannya(Prasetya,2012).

Sejak diberlakukannya Undang-Undang Republik Indonesia Nomor 28 Tahun 2004 tentang Perubahan Undang-Undang Republik Indonesia Nomor 16 Tahun 2001 tentang Yayasan diakui sebagai badan hukum privat yang berarti diakui sebagai subjek hukum mandiri yang kedudukan subjek hukumnya para pendiri atau pengurusnya dengan adanya hukum positif tersebut yang tertuang dalam aturan-aturan tertulis yang secara jelas dan lengkap maka memberikan landasan yuridis yang jelas terhadap yayasan.

Beraneka ragam bentuk atau wujud yayasan sesuai dengan tujuannya oleh sebab itu memunculkan pertanyaan, apakah semua yayasan yang telah berdiri di lingkungan masyarakat telah menjadi badan hukum mengingat salah satu tujuan berdirinya yayasan adanya fungsi sosial didalamnya yang semata- mata lembaga ini ada untuk didedikasikan kepada golongan yang membutuhkan bantuan bukan mencari profit. (Chatamarrasyid, 2002). Yayasan yang bergerak dibidang sosial hal ini disebabkan banyak yayasan yang melakukan tindakan hukum untuk memperoleh suatu pencapaian atau tujuan terhadap berdirinya suatu yayasan.

Munculnya yayasan dengan berbagai persyaratan sesuai pemberlakuan Undang-Undang Republik Indonesia Nomor 16 Tahun 2001 tentang Yayasan bahwa yayasan dapat dikatakan sebagai badan hukum apabila telah memenuhi anggaran dasarnya sesuai undang-undang yang telah ditentukan. Dengan pemberlakuannya undang-undang tentang yayasan maka yayasan dapat dikatakan suatu badan hukum yang keberadaannya diakui sebagai subjek hukum mandiri terlepas dari kedudukan subjek hukum dari para pendiri ataupun pengurusnya. Selain itu dengan adanya hukum 
positif dalam aturan-aturan tertulis secara jelas dalam undang- undang yayasan maka memberikan landasan yuridis mengenai yayasan.

Berdasarkan ketentuan Pasal 71 Ayat 1 dan Ayat 2 bahwa Undang-Undang Yayasan yang belum menyesuaikan anggaran dasar harus segera menyeseuaikan dengan jangka waktu yang ditentukan. Akan tetapi mengingat jangka waktu yang telah ditentukan telah habis yakni paling lambat 3 (tiga) tahun maka hal tersebut memunculkan permasalahan yang mengakibatkan yayasan tersebut tidak memiliki status sebagai badan hukum. Hasil pemaparan dari latar belakang yang telah diberikan oleh penulis maka penulis tertarik untuk melakukan penelitian mengenai status kedudukan hukum bagi yayasan mengenai anggaran dasar yang tidak menyesuaikan setelah pemberlakuan Undang- undang nomor 28 tahun 2004 tentang perubahan Undang- undang Nomor 16 tahun 2001 tentang yayasan.

Penjelasan yang telah dipaparkan diatas dapat ditarik rumusan masalah yakni sebagai berikut bagaimana status kedudukan hukum pada yayasan sebagai badan hukum yang tidak menyesuaikan anggaran dasar sesuai dengan ketentuan pasal 71 ayat 4 Undang- undang Nomor 28 tahun 2004 tentang perubahan undang- undang Nomor 16 Tahun 2001 tentang Yayasan dan bagaimana implikasi yuridisnya jika yayasan yang tidak menggunakan kata "yayasan" dalam melakukan tindakan hukum.

\section{Metode Penelitian}

Penulisan penelitian ini menggunakan jenis penelitian yuridis Normatif (legal research). Penelitian yangmengkaji dan menganalisis sesuai dengan ketentuan hukum positif (peraturan perundang-undangan) dengan mengkaitkan dari satu pasal kepasal yang lain. Metode pendekatan yang digunakan dalam penelitian ini adalah pendekatan perundang-undangan (statute approach) dalam mengkaji dan menganalisis permasalahannya de- ngan menelaah seluruh undang-undang dan regulasi. Sumber bahan hukum yang digunakan yaitu menggunakan sumber hukum primer, sekunder dan tersier. Teknik pengumpulan bahan hukum yang digunakan oleh penulis adalah teknik pengumpulan data dengan studi pustaka terhadap bahanbahan hukum.

\section{Kedudukan Hukum Yayasan sebagai Badan Hukum Ketika Tidak Menyesuaikan Anggran Dasarnya}

Yayasan berdasarkan ketentuan Pasal 1 Angka 1 Undang-Undang Republik Indonesia Nomor 16 Tahun 2001 tentang Yayasan, bahwa yayasan merupakan harta kekayaan yang tersendirikan untuk tujuan tertentu yaitu untuk kepentingan sosial, keagamaan, dan kemanusiaan dan tidak memiliki anggota. Yayasan sebagai lembaga yang mempunyai maksud dan tujuan hal tersebut telah diatur pada Pasal 7 dan Pasal 8 Undang-Undang Republik Indonesia Nomor 16 Tahun 2001 tentang Yayasan bahwa yayasan dapat mendirikan badan usaha yang dalam kegiatannya sesuai dengan maksud dan tujuan yayasan.

Mengenai kepentingan yayasan yang terletak kepada para anggotanya sebab yayasan tidak mempunyai anggota dan pemegang kekeuasaan tertinggi dari yayasan adalah pengurusnya. Pengurus adalah jabatan yang menentukan maksud dan tujuan dari suatu yayasan. Yayasan yang bergerak dibidang sosial dalam pendiriannya mengenai anggaran dasar bahwa pada prakteknya pendiri yayasan dapat mengajukan berupa draft statute dengan memasukkan atau diakomodasikan ke dalam statute standart dari Kementerian Menteri Hukum dan Hak Asasi Manusia yang diberlakukan kemudian diperkenankan kepada semua jenis pendirian yayasan baik dibidang sosial, keagamaan, dan kemanusiaan. Pendirian yayasan berdasarkan peraturan perundang-undangan menyatakan bahwa pada prosesnya melalui beberapa tahap baik secara 
online dan pembuatan akta pendirian yayasan di hadapan Notaris.

Pendirian yayasan yang dilakukan oleh Notaris sebagai langkah pendirian dan pengesahan badan hukum yayasan melalui Administrasi Hukum Umum yang kemudian disingkat menjadi AHU online, merupakan langkah pendirian yang telah diatur oleh undang-undang yag berlaku. Bahwa pendirian perkumpulan yang berbadan hukum harus dibuat dengan akta Notaris. Proses pendirian yayasan yang dilakukan via online yang dilakukan notaris bekerjasama dengan Kementerian Hukum dan Hak Asasi Manusia Republik Indonesiayang selajutnya disingkat menjadi Kemenkuham bahwa Notaris harus memiliki akun untuk layanan Administasi Hukum Umum (AHU) online. Hal ini berguna sebagai verifikasi data dan profil notaris sesuai profesi yang dijalaninya. Notaris dengan akun yang diberikan oleh Administrasi Hukum Umum memiliki laman khusus yang berisikan dengan profil, pesan dan menu untuk keperluan mengurus badan hukum secara online.

Sistem yang baru berjalan sejak tahun 2015 bertujuan untuk memudahkan pelayanan terhadap masyarakat agar dalam proses pendirian maupun adminsitrasi diharapkan mendapatkan kemudahan. Di era mobile sekarang dibutuhkan dan hukum harus tetap menjadi acuan utama dengan adanya teknologi ini. Sehingga dengan sistem AHU online ini pada implementasinya proses pendirian maupun hal- hal penting yang berkaitan dengan badan hukum dapat berjalan sesuai dengan prosedur dan tidak menyalahi ketentuan perundang-undangan.

Anggaran dasar yang merupakan dasar landasan berdirinya suatu lembaga yakni yayasan. Syarat anggaran dasarantara lain sesuai dengan Pasal 14 (1) dan (2) Undang-Undang Yayasan sebagai berikut:

(1) Akta pendirian memuat Anggaran Dasar dam keterangan lain dianggap perlu;

(2) Anggaran dasar yayasan sekurang- kurangnya memuat: a. Nama dan tempat kedudukan;

b. Maksud dan tujuan serta kegiatan untuk mencapai maksud dan tujuan tersebut;

c. Jangka waktu pendirian;

d. Jumlah kekayaan awal yang dipisahkan dari kekayaan pribadi pendiri dalam bentuk uang atau benda;

e. Cara memperoleh dan penggarungan kekayaan;

f. Tata cara pengangkatan, pemberhentian, dan penggantian anggota Pembina, Pengurus, dan Pengawas;

g. Hak dan kewajiban anggota Pembina, Pengurus, dan Pengawas;

h. Tata cara penyelenggaraan rapat organ Yayasan;

i. Ketentuan mengenai perubahan anggaran dasar;

j. Penggabungan dan pembubaran yayasan; dan

k. Penggunaan kekayaan sisa likuidasi atau penyaluran kekayaan Yayasan setelah pembubaran.

Berdasarkan ketentuan tersebut diatas bahwa untuk mendirikan suatu yayasan harus sekurang-kurangnya memenuhi persyaratan sesuai ketentuan Undang-Undang Yayasan. Anggaran dasar tersebut merupakan suatu wujud yayasan bahwa lembaga tersebut telah aktif untuk menjalankan maksud dan tujuannya. Sehingga pentingnya anggaran dasar tersebut dalam yayasan dengan melihat prihal pertimbangan didalam Peraturan Pemerintah Republik Indonesia Nomor 2 Tahun 2013 bahwa sampai saat ini masih terdapat yayasan yang belum menyesuaikan anggaran dasar dengan peraturan perundang-undangan yang berlaku.

Anggaran dasar sebagai acuan yang yayasan wajib menyesuaikan anggaran dasarnya sesuai dengan Undang-Undang Republik Indonesia Nomor 16 Tahun 2001 tentang Yayasan yang sebagaimana telah dilakukannya perubahan dengan Undang- 
Undang Republik Indonesia Nomor 28 Tahun 2004 tentang Yayasan, agar memperoleh status badan hukum yayasan dan tetap diakui yayasan sebagai lembaga berbadan hukum.

Anggaran dasar yang diubah berdasarkan Pasal 17 Undang-Undang Republik Indonesia Nomor 16 Tahun 2001 tentang Yayasan, anggaran dasar yayasan dapat diubah kecuali mengenai "maksud" dan "tujuan" yayasan yang menurut anggaran dasar yang baku harus dicantumkan dalam Pasal 2 Anggaran dasar sebab anggaran dasar merupakan unsur esensial dari suatu lembaga yayasan.(Suparmono, 2008). Perubahan anggaran dasar tersebut tidak bisa serta merta dirubah harus ada beberapa syarat yang harus dipenuhi antara lain: Syarat sah dilakukannya perubahan anggaran dasar tersebut harus dipenuhi sebagai berikut:

1. Harus diputuskan oleh rapat Pembina (Pasal 18 Ayat (1) UU No. 16 Tahun 2001);

2. Dengan forum rapat Pembina sekurangkurangnya 2/3 (Pasal 18 Ayat (2) UU No. 16 Tahun 2001, dan manakala kuorum ini tidak tercapai maka dapat diselenggarakan rapat yang kedua yang untuk rapat yang kedua ini cukup dengan kuorum 1/2 (Pasal 20 Ayat (2) UU No. 16 Tahun 2001);

3. Disetujui sekurang- kurangnya oleh $2 / 3$ dari yag hadir (Pasal 19 (1)); dan diadakan rapat kedua maka cukup sah disetujui oleh suara terbanyak (Pasal 20 Ayat (3) UU No. 16 Tahun 2001);

4. Dengan membuat akta notaris dalam bahasa Indonesia (Pasal 18 Ayat (3) UU No. 16 Tahun 2001).

Yayasan yang didirikan sebelum maupun setelah diberlakukannya Undang- undang Nomor 16 tahun 2001 tentang Yayasan bahwa status sebagai sebuah badan hukum yang memberikan atribut kepada yayasan, samaseperti halnya yang melekat terhadap manusia sebagai suatu subjek hukum yang alamiah (natuurlijkepersoon) diantaranya bahwa yayasan memiliki kekayaan sendiri dan bertindak secara hukum atas nama sendiri melalui para pengurusnya (Pasaribu, et. al. 2013). Yayasan sebagai lembaga yang berbadan hukum agar diakui harus memenuhi beberapa persyaratan antara lain:

1. Syarat materiil yang terdiri dari harus ada pemisahan harta kekayaan adanya tujuan tertentu dan memiliki organisasi; dan

2. Syarat formil yaitu didirikan dengan akta otentik dihadapan Notaris.

Terkait yayasan yang tidak menyesuaikan anggaran dasarnya tentu akan memberikan dampak terhadap perbuatan atau tindakan hukum yang diberikan. Bahwa dengan tidak menyesuaikan anggaran dasar tersebut memberikan status kedudukan hukum yayasan tersebut menjadi tidak jelas. Aturan hukum mengenai yayasan yang tidak menyesuaikan anggaran dasar dalam peraturan perundang- undangan tidak jelas diatur sehingga aturan hukum yang bersangkutan dan tidak memiliki kekuatan hukum mengikat. Pasal 39 Peraturan Pemerintah Republik Indonesia Nomor 63 Tahun 2008 tentang Pelaksanaan Undang-Undang Yayasan bahwa:"Yayasan yang belum memberitahukan kepada Menteri sesuai dengan ketentuan sebagaimana dimaksud dalam Pasal 71 Ayat (3) Undang-Undang Yayasan tidak dapat menggunakan kata "yayasan" didepan namanya sebagaimana yang dimaksud dalam Pasal 71 Ayat (4) Undang-Undang Yayasan dan harus melikudiasi kekayaannya serta menyerahkan sisa hasil likuidasi sesuai dengan ketentuan sebagaimana dimaksud dalam Pasal 68 Undang-Undang Yayasan".

Berdasarkan ketentuan diatas bahwa yayasan yang belum memberitahukan kepada menteri mengenai anggaran dasarnya akan memperoleh sanksi bahwa yayasan tersebut tidak diperbolehkan menggunakan "yayasan". (Bahari,2010). Pembahasan yang dilakukan peneliti dapat dibedakan antara belum diberitahukan dan tidak menyesuaikan terkait anggaran dasar tersebut. Jika me- 
lihat hal tersebut tentu keduanya akan mendapatkan dampak akibat hukum yang berbeda. Bahwa dengan kata "belum menyampaikan informasi" mengandung makna dalam hal ini terjadinya penundaan penyesuaian anggaran dasar yayasan yang telah diberikan jangka waktu sesuai ketentuan peraturan perundang-undangan yaitu Undang-Undang Yayasan. Berbeda halnya dengan tidak melakukan penyesuaian anggaran dasar yayasan tentu hal ini memberikan dampak terhadap yayasan tersebut.

Status Kedudukan yayasan yang tidak lagi memiliki hak menggunakan kata yayasan didepan namanya menimbulkan tanda tanya. Hal tersebut mengingat status yang diberikan kepada yayasan yang tidak menggunakan kata "yayasan" didepannya dalam melakukan perbuatan hukum dinilai tidak memiliki status kedudukan hukum yang jelas. (Prasetya, 2012). Secara subtansi Pasal 39 Peraturan Pemerintah Republik Indonesia Nomor 63 Tahun 2009 tersebut dapat ditafsirkan bahwa yayasan dalam keadaan itu dapat lansung dilikuidasi tanpa adanya pembubaran yang artinya yayasan tersebut dianggap telah bubar demi hukum. Yayasan untuk dapat memperoleh suatu badan hukum setelah yayasan tersebut telah dibuatkannya akta pendirian, maka akta pendiriannya tersebut wajib untuk mendapatkan pengesahan dari Menteri Hukum dan Hak Asasi Manusia dengan pengecualian bagi yayasan yang berdiri sebelum diberlakukannya undang- undang yayasan yang telah berdiri dan didaftarkan di Pengadilan Negeri dan diumumkan dalam Tambahan Berita Negara Republik Indonesia, dan/ atau mendapat izin kegiatan dari instansi terkait (Pasaribu, 2013).

Yayasan yang akta pendiriannya belum memperoleh pengesahan dari Menteri Hukum dan Hak Asasi Manusia secara otomatis yayasan tersebut belum memperoleh status badan hukum, sehingga dengan demikian tidak memiliki hak untuk memakai kata "yayasan" didepan namanya mengingat Pasal 1 Angka 1 Undang-Undang
Yayasan secara tegas menyatakan bahwa yayasan merupakan suatu badan hukum yang juga diatur ketentuannya dalam Pasal 15 Ayat 2 UndangUndang Yayasan dengan menyebutkan nama yayasan harus didahului dengan kata "yayasan" (Suparmono, 2008). Pasal 71 Ayat (2) UndangUndang Yayasan diwajibkan untuk menyesuaikan anggaran dasarnya dengan peraturan perundangundangan yayasan serta mengajukan permohonan pengesahan badan hukum kepada Menteri Hukum dan Hak Asasi Manusia Republik Indonesia.

Selain itu Pasal 71 menyatakan lembaga yayasan dalam hal anggaran dasarnya melihat ketentuan yang diatur dalam Pasal 39 Peraturan Pemerintah Republik Indonesia Nomor 63 Tahun 2008, yang menentukan bahwa yayasan yang belum memberitahukan kepada Menteri sesuai dengan ketentuan sebagaimana dimakusd dalam Pasal 71 Ayat 3 Undang-Undang Yayasan tidak dapat menggunakan kata "Yayasan" didepan namanya." Dua syarat yang ditujukan ini apabila terpenuhi dapat dijadikan acuan untuk membuat penyesuaian anggaran dasar untuk disesuaikan dengan ketentuan Undang-Undang Yayasan dan melaporkan penyesuaian tersebut kepada Menteri Hukum dan Hak Asasi Manusia sehingga bukti penerimaan laporan penyesuaian inilah sebagai bukti bahwa yayasan tersebut sebagai badan hukum (Suharto,2009).

Status kedudukan hukum nya batal demi hukum dan harus segera dibubarkan dan dilikuidasi. Sebab yayasan tersebut tidak memiliki kekuatan hukum mengikat mengingat anggaran dasar merupakan dasar landasan suatu lembaga tersebut berdiri yakni yayasan. Status kedudukan hukum yang akhirnya memberikan ketidakjelasan terhadap yayasan yang akhirnya tidak memberikan dasar hukum yang kuat untuk melindungan dan memberikan kepastian terhadap tindakan hukum yang dikeluarkan. Anggaran dasar yang mengalami perubahan anggaran dasar tidak dapat dilakukan jika dinyatakan dalam keadaan pailit 
kecuali dengan persetujuan curator sesuai ketentuan pasal 23 Undang-Undang Republik Indonesia Nomor 16 Tahun 2001 (Lisman,1997).

\section{Implikasi Yuridis Mengenai Yayasan yang tidak dapat Menggunakan Kata "Yayasan" di Depan Nama Yayasan dalam Melakukan Tindakan Hukum}

Yayasan merupakan lembaga hukum yang memiliki kekuatan hukum mengikat. Eksistensi yayasan diakui di Indonesia baik sebelum diberlakukakannya Undang-Undang Yayasan maupun setelah adanya Undang-Undang Yayasan. Setelah adanya Undang-Undang Yayasan sebagai hukum positif di Indonesia, yayasan semakin jelas keberadaannya di Indonesia (Prasetya,2012).

Yayasan berdasarkan ketentuan peraturan perundang-undangan yang berlaku dalam menjalankan kegiatannya dibidang yakni sosial, keagamaan dan kemanusiaan. Dilahirkannya UndangUndang Yayasan ini maka diharapkan dapat mengatasi dan menjadi tumpu acuan untuk menyelesaikan permasalahan mengenai yayasan kedepannya. Namun implementasi dari undang-undang Yayasan dalam perkembangannya belum bisa menampung seluruh kebutuhan yang diperlukan yayasan dan perkembangan hukum didalam masyarakat. (Budiono,2013).

Keberdaan yayasan saat ini meskipun telah lahir undang-undang yang mengaturnya masih tetap saja dalam prakteknya timbul berbagai berbagai permasalahan dari awal pendirian yayasan sampai berakhirnya yayasan tersebut. Hal tersebut sebenarnya memberikan arti bahwa undangundang yayasan tersebut belum sepenuhnya memberikan kemudahan dan jalan keluar terhadap permasalahan yang timbul. Mengingat dengan aturan dalam Undang-Undang Yayasan Pasal 71 Ayat (4):

"yayasan yang tidak menyesuaikan anggaran dasarnya dalam jangka waktu sebagaimana yang dimaksud pada ayat (1) dan yayasan sebagaimana dimaksud pada ayat (2), tidak dapat menggunakan kata "yayasan" didepan namanya dam dapat dibubarkan berdasarkan putusan Pengadilan atas permohonan Kejaksaan atau pihak yang berkepentingan".

Berdasarkan dengan ketetntuan diatas bahwa dikatakan secara tegas yayasan yang tidak menyesuaikan anggaran dasar tidak dapat menggunakan kata "yayasan" didepan memberikan dampak bagi yayasan tersebut. Yayasan yang tidak diberikan kewenangan menggunakan kata "yayasan" sesuai ketentuan undang-undang yayasan jika masih menginginkan eksistensi dari yayasan tersebut harus segera menyesuaikan anggaran dasarnya. (Budiono, 2013). Syarat untuk mempertahankan eksistensi yayasan tersebut antara lain paling sedikit 5 (lima) tahun berturut-turut sebelum melakukan penyesuaian harus masih melakukan kegiatan sesuai anggaran dasarnya dan belum pernah dibubarkan.

Sebagaimana dimaksud dalam Pasal 71 Ayat 4 dan harus melikuidasi kekayaannya serta menyerahkan sisa hasil likuidasi sesuai ketentuan sebagaimana dimaksud dalam Pasal 68 UndangUndang Republik Indonesia Nomor 16 Tahun 2001 tentang Yayasan. Pengertian likuidasi adalah suatu perusahaan yang melakukan penghentian, pemberesan, penjualan obral,penjualan barang-barang yang masih ada yang semua usahanya menjual barang-barangnya dan kemudian mengadakan perhitungan terakhir untuk menyelesaikan hutang piutang. Likuidasi merupakan tindakan yang menentukan dengan cara kesepakatan atau melalui litigasi jumlah secara pasti sebagai hutang atau biaya yang sebelumnya tidak pasti. Selain itu juga likuidasi tindakan yang bertujuan untuk menyelesaikan hutang piutang degan cara pembayaran ataupun cara lain serta dengan penggantian asset menjadi kas/uang tunai untuk menyelesaikan hutang piutang. 
Penggunaan kata "yayasan" didepan namanya badan hukum dalam perbuatan hukumnya menimbulkan kekaburan terhadap makna kata "yayasan" sebagai nama dari sebuah badan yang diakui sebagai badan hukum, sekaligus menimbulkan kesulitan dalam upaya apabila mengajukan gugatan terhadap badan ini jika melalui organnya melakukan suatu perbuatan melawan hukum. (Anwar, 2010).

Praktiknya menjadi suatu persoalan tersendiri bagi yayasan yang tidak dapat menggunakan kata yayasan dan yang belum menyesuaikan anggaran dasarnya dengan Undang-Undang Yayasan, yaitu bagaimana yayasan tersebut melakukan kegiatannya Undang-Undang Yayasan Pasal 71 Undang-Undang ini mulai berlaku, Yayasan yang: (a) telah didaftarkan di Pengadilan Negeri dan diumumkan dalam Tambahan Berita Negara Republik Indonesia; atau (b) telah didaftarkan di Pengadilan Negeri dan mempunyai izin melakukan kegiatan dari instansi terkait; tetap diakui sebagai badan hukum dengan ketentuan dalam jangka waktu paling lambat 3 (tiga) tahun terhitung sejak tanggal Undang-Undang ini mulai berlaku, Yayasan tersebut wajib menyesuaikan Anggaran Dasarnya dengan ketentuan Undang-undang ini. (Prasetya, 2012).

Yayasan yang telah didirikan dan tidak memenuhi ketentuan sebagaimana dimaksud pada ayat (1), dapat memperoleh status badan hukum dengan cara menyesuaikan Anggaran Dasarnya dengan ketentuan Undang-undang ini, dan mengajukan permohonan kepada Menteri dalam jangka waktu paling lambat 1 (satu) tahun terhitung sejak tanggal Undang-undang ini mulai berlaku.Yayasan sebagaimana dimaksud pada ayat (1), wajib diberitahukan kepada Menteri paling lambat 1 (satu) tahun setelah pelaksanaan penyesuaian.Yayasan yang tidak menyesuaikan Anggaran Dasarnya dalam jangka waktu sebagaimana dimaksud pada ayat (1) dan Yayasan sebagaimana dimaksud pada ayat (2), tidak dapat menggunakan kata "yayasan" di depan namanya dan dapat dibubarkan berdasarkan putusan Pengadilan atas permohonan Kejaksaan atau pihak yang berkepentingan. (Bahari, 2010).

Pasal 1653 Kitab Undang-Undang Hukum Perdata, Perkumpulan adalah selainnya perseroan yang sejati oleh undang-undang diakui pula perhimpunan-perhimpunan orang sebagai perkumpulanperkumpulan, baik perkumpulan- perkumpulan itu diadakan atau diakui sebagai demikian oleh kekuasaan umum maupun perkumpulan-perkumpulan itu diterima sebagai diperbolehkan, atau telah didirikan untuk suatu maksud tertentu yang tidak bertentangan dengan undang-undang atau kesusilaan baik. Menanggapi persoalan dengan yayasan sebagai perkumpulan saja karena pada praktiknya masih menggunakan kata yayasan. (Suparmono, 2008).

Hal ini tentunya akan menimbulkan ketidak pastian hukum yayasan sebab pengaturan hukum antara badan hukum perkumpulan dengan suatu yayasan berbeda. Dengan mengkaitkan teori kepastian hukum yang bahwa aturan sanksi kepada yayasan yang tidak menggunakan kata "yayasan" memberikan jawaban bahwa apabila yayasan tersebut tidak behak menggunakan yayasan maka statusnya menjadi badan perkumpulan saja yang tujuannya memberikan kepastian hukum terhadap lembaga akan seperti apa jika tidak menggunakan yayasan tersebut.

Undang-Undang yayasan yang terdapat aturan bahwa yayasan yang telah didirikan sebelumnya berlakunya Undang-Undang Yayasan akan tetapi tidak diakui sebagai badan hukum wajib menyesuaikan anggaran dasar yayasan dan mengajukan permohonan pengesahan badan hukum, dengan ketentuan jika tidak memenuhi dalam 1 tahun semenjak diberlakukannya Undang-Undang Republik IndonesiaNomor 28 Tahun 2004 tentang Yayasan maka terhadap yayasan tidak berhak menggunakan nama "yayasan". 


\section{Simpulan}

Berdasarkan uraian di atas disimpulan bahwa yayasan yang anggaran dasarnya tidak sesuai dengan ketentuan yang berlaku harus segera disesuaikan. Jika tidak disesuaikan anggaran dasarnya maka yayasan tersebut secara otomatis akan dilikuidasi. Berkaitan dengan anggaran dasar yayasan yang tidak menyesuaikan, maka yayasan tersebut tidak diberikan kewenangan untuk menggunakan kata "yayasan" di depan nama yayasan sesuai dengan ketentuan Pasal 71 Ayat (4) Undang Undang Yayasan.

Dengan demikian implikasi dari yayasan tersebut adalah bahwa yayasan tidak memiliki kekuatan hukum mengikat dan yayasan tersebut bukan lagi menjadi Badan Hukum secara otomatis. Implikasi berikutnya adalah bahwa yayasan tersebut tidak terlindungi oleh payung hukum jika mengalami permasalahan hukum.

\section{Saran}

Pengurus yayasan untuk selalu mengikuti prosedur yang berlaku sesuai dengan ketentuan peraturan perundang-undangan yang berlaku. Jika tidak, maka hal ini akan merugikan pihak yang berkepentingan. Bahwa untuk itu kiranya juga diperlukan adanya pengaturan lebih jelas dan tegas dalam bentuk peraturan terhadap lembaga yayasan untuk memberikan kejelasan kedudukan yayasan di hadapan hukum.

\section{DAFTAR PUSTAKA}

Adjie, Habib. 2013. Menjalin Pemikiran-Pendapat tentang Kenotariatan. Citra Aditya Bakti. Bandung.

Ali, C. 1999. Badan Hukum. Alumni. Bandung.

Anwar, Borahima. 2010. Kedudukan Yayasan di Indonesia: Eksistensi, Tujuan dan Tanggung Jawab Yayasan. Kencana. Jakarta.

Bahari, Adib. 2010. Prosedur Pendirian Yayasan. Pustaka Yustisia. Yogyakarta.
Budiono, Herlien. 2013. Kumpulan Tulisan Hukum Perdata dibidang Kenotariatan, Edisi buku Kedua, Citra Aditya Bakti, Bandung.

Chatamarrasjid. 2002. Badan Hukum Yayasan (Suatu Analisis Mengenai Yayasan Sebagai Suatu Badan Hukum Sosial). Citra Aditya Bakti. Bandung.

Chatamarrasyid. 2002. Tujuan Sosial Yayasan dan Kegiatan Usaha Bertujuan Laba. Citra Aditya Bakti. Bandung.

Kitab Undang-Undang Hukum Perdata, Burgerlijk Wetboek.

Lisman, Iskandar. 1997. Aspek Hukum Yayasan Menurut Hukum Positif di Indonesia. Majalah Yuridika No 5 \& 6 Tahun XII September-Desember.

Pasaribu, Benhard Kurniawan, Sihabuddin, Suhariningsih. 2013. Pertanggungjawaban Hukum Yayasan yang Tidak Memenuhi Ketentuan Pasal 71 Ayat (2) UU Yayasan Terhadap Pelaksanaan Eksekusi Putusan Berkekuatan Hukum Tetap. Jurnal Hukum. 1-22.

Peraturan Pemerintah Republik Indoneisa Nomor 02 Tahun 2013 tentang Perubahan Atas Peraturan Pemerintah Republik Indonesia Nomor 63 Tahun 2008 tentang Pelaksanaan Undang-Undang tentang Yayasan.Jakarta.

Peraturan Pemerintah Republik Indonesia Nomor 63 Tahun 2008 tentang Pelaksanaan Undang-Undang Tentang Yayasan.Jakarta.

Prasetya, Rudhi. 2012. Yayasan Teori dan Praktek. Sinar Grafika. Jakarta.

Septiari, Riska, Firdaus, Ulfia Hasanah. 2016. Tinjauan Yuridis Terhadap Pendirian Yayasan Pendidikan Sebagai Kegiatan Usaha yang Bersifat Komersil Berdasarkan Undang-Undang Nomor 16 Tahun 2001 Tentang Yayasan Jo. Undang-Undang Nomor 28 Tahun 2004. Jurnal Online Mahasiswa Fakultas Hukum. Vol. III No. 2. Oktober. 1-13.

Sjaifurrachman. 2011. Aspek Pertanggungjawaban Notaris dalam Pembuatan Akta. Mandar Maju. Surabaya.

Suharto, 2009, Membedah Konflik Yayasan, Gramedia, Yogyakarta.

Suparmono, Gatot. 2008. Hukum Yayasan di Indoensia. Rhineka Cipta. Jakarta. 


\section{Analisis Yuridis terhadap Yayasan yang Tidak Menyesuaikan Anggaran Dasarnya}

Nury Anisa, Tunggul Anshari, Nurdin

Undang-Undang Republik Indonesia Nomor 16 Tahun 2001 tentang Yayasan. Jakarta.

Undang-Undang Republik Indonesia Nomor 2 Tahun 2014 tentang Perubahan Atas Undang-Undang Republik Indonesia Nomor 30 tahun 2004 tentang Jabatan Notaris.Jakarta.

Undang-Undang Republik Indonesia Nomor 28 Tahun 2004 tentang Perubahan atas Undang-Undang Republik Indonesia Nomor 16 Tahun 2001 tentang Yayasan.Jakarta.
Undang-Undang Republik Indonesia Nomor 30 Tahun 2004 tentang Jabatan Notaris.Jakarta.

\section{How to Cite:}

Anisa, Nury, Tunggul Anshari, Nurdin. 2017. Analisis Yuridis Terhadap Yayasan yang Tidak Menyesuaikan Anggaran Dasarnya. Jurnal Cakrawala Hukum. 8 (1): 96-105. 